\title{
Effect of Obesity on Serum Vitamin D Metabolites Using Obese Zucker Rat Model
}

\author{
Stepan Melnyk ${ }^{1,2}$, Teresa Evans ${ }^{1,2}$, Soheila Korourian ${ }^{3}$ and Reza Hakkak ${ }^{1,2,4^{*}}$ \\ ${ }^{1}$ Department of Pediatrics, University of Arkansas for Medical Sciences, USA \\ ${ }^{2}$ Arkansas Children's Hospital Research Institute, USA \\ ${ }^{3}$ Department of Pathology, University of Arkansas for Medical Sciences, USA
}

${ }^{4}$ Department of Dietetics and Nutrition, University of Arkansas for Medical Sciences, USA

"Corresponding author: Reza Hakkak, Department of Dietetics and Nutrition, University of Arkansas for Medical Sciences, USA, Tel: 501-686-6166; Fax: 501-686-5716; E-mail: RHakkak@uams.edu

Rec date: Jul 31, 2014; Acc date: Sep 16, 2014; Pub date: Sep 24, 2014

Copyright: ( 2014 Melnyk S, et al. This is an open-access article distributed under the terms of the Creative Commons Attribution License, which permits unrestricted use, distribution, and reproduction in any medium, provided the original author and source are credited.

\begin{abstract}
The obesity epidemic in the US has continued for over two decades as the proportion of overweight and obese adults in the population continues to rise. Also, obesity has been linked with the risk of development of various diseases such as diabetes, cardiovascular disease and certain types of cancers. There are conflicting reports about the effects of obesity on serum vitamin D levels in human and animal models. We hypothesize that obesity will affect the serum levels of vitamin D metabolites. Therefore, the objective of this study was to investigate the influence of obesity on the serum concentrations of two metabolites of vitamin D [25- $(\mathrm{OH})-\mathrm{D}$ and $\left.1,25-(\mathrm{OH})_{2}-\mathrm{D}\right]$ in rats. Sixteen 5-week-old female Zucker rats ( 8 obese fa/fa and 8 lean) were acclimated for one week, and at the age of 42 days, the rats were housed 2 per cage with ad libitum access to water and AIN-93G diet. Rats were weighed twice weekly. At the end of the experiment ( 8 weeks), all rats were sacrificed and serum was collected and stored at $-20^{\circ} \mathrm{C}$. Serum concentrations of $25-\mathrm{OH}-\mathrm{D}$ and $1,25-(\mathrm{OH})_{2}-\mathrm{D}$ were measured using HPLC-UV. Data were analyzed using Excel software and presented as mean \pm SD. Obese rats had significant weight gain $(P<0.001)$. Serum concentration of $25-(\mathrm{OH})-\mathrm{D}$ metabolite in obese rats was significantly $(\mathrm{P}<0.05)$ lower compared to lean rats. At the same time, serum concentration of $1,25-(\mathrm{OH})_{2}-\mathrm{D}$ metabolite in obese rats was only $8 \%$ lower and did not significantly $(P<0.3)$ change compared to the lean group. The serum ratio of $1,25-(O H) 2-D: 25-(O H)-D$ was approximately $10 \%$ higher $(\mathrm{P}<0.3)$ in obese rats compared to the lean group. In summary, lower serum concentration of 25-OH-D (hormonally inactive form of vitamin D) metabolite is consistent with higher body mass in rats, but obesity did not affect the serum concentration of $1,25-(\mathrm{OH})_{2}-\mathrm{D}$. Our results show that the obese Zucker rat can be a good model for assessing vitamin $D$ status.
\end{abstract}

Keywords: Obesity; Zucker rats; Vitamin D

\section{Introduction}

The obesity epidemic in the US has continued to rise over two decades. The proportion of overweight and obese adults to normal weight adults in the population is continuing to increase. It has been reported that approximately $70 \%$ of Americans over 60 years of age are obese or overweight $[1,2]$. Obesity has been linked with the risk of development of various diseases such as diabetes, cardiovascular disease and certain types of cancers [3-5].

The research community is focusing much attention studying the pathogenesis of obesity. One of the multivectoral approaches is to determine the relationship between obesity and vitamin D status. Results from some studies indicate that obese humans have lower serum vitamin $\mathrm{D}$ concentration in blood [6,7]. It has also been reported that obesity in humans is accompanied with a change in the levels two vitamin $\mathrm{D}$ metabolites in plasma: lower concentrations of $25-\mathrm{OH}-\mathrm{D}$ and higher concentrations of $1,25-(\mathrm{OH})_{2}$-D [8-11]. It has also been reported that young adults taking vitamin $\mathrm{D}$ supplements have a higher incidence of overweight and obesity [12] compared to young adults of normal weight. Lately, it has been reported that vitamin $\mathrm{D}$ concentration was lower in obese and overweight adolescents than in overweight children $[13,14]$.

On the other hand, there are discrepancies between vitamin D status collected from human and animal/rodent models [15]. A vitamin $\mathrm{D}$ study in obese Zucker fa/fa rats with hyperinsulinemia showed an increase of plasma insulin and calcium and no significant changes in vitamin $\mathrm{D}$ concentrations or ratios of $1,25-(\mathrm{OH})_{2}-\mathrm{D}$ to $25-$ OH-D compared to lean littermates [16]. However, other studies found that obese animals had lower levels of serum and plasma 1,25$(\mathrm{OH})_{2}-\mathrm{D}$ compared to lean animals $[17,18]$. Also, age, gender and sex hormones can change the status of vitamin D in humans $[19,20]$. This confusing data needs to be clarified. Therefore, the objective of this study was to investigate the influence of obesity on the direction of changes in vitamin $\mathrm{D}$ metabolites in an animal model and to determine if obese Zucker rat model can be used to extrapolate data to humans and study one aspect of pathogenic relation of obesity and vitamin D status.

\section{Methods}

The animal protocol for this study was approved by the Institutional Animal Care and Use Committee of the University of Arkansas for Medical Sciences. Sixteen 5-week-old female Zucker rats 
( 8 obese fa/fa and 8 lean) were acclimated for one week. At the age of 42 days, rats were housed 2 per cage with ad libitum access to water and AIN-93G diet as previously reported [21,22]. Rats were weighed twice weekly. At the end of the experiment (8 weeks), all rats were sacrificed and serum was collected and stored at $-20^{\circ} \mathrm{C}$ for later analysis.

Serum concentrations of $25(\mathrm{OH})-\mathrm{D}$ and $1,25-(\mathrm{OH})_{2}-\mathrm{D}$ were measured using an HPLC-UV method [23] as a basic with analytical equipment from Thermo Scientific (Waltham, MA).

Briefly, the vitamin D metabolites $25(\mathrm{OH})-\mathrm{D}$ and $1,25-(\mathrm{OH})_{2}$ were purchased from Sigma-Aldrich (St. Louis, MO). All reagents were HPLC grade. Acetonitrile, ethyl acetate and methanol were obtained from Fluka (St. Louis, MO). Ultrapure water $(18.2 \mathrm{M} \Omega / \mathrm{cm})$ was obtained from a MilliQ water purification system (Millipore, Billerica, MA). The HPLC unit was an integrated system with a UV3000 Ultra detector set at $275 \mathrm{~nm}$, a pump set at $1.2 \mathrm{~mL} / \mathrm{min}$, and an auto-sampler for injection $(10 \mu \mathrm{L})$, all from Thermo Separation Products (Waltham, MA). A column $(\mathrm{C} 18,3 \mu \mathrm{m}, 4.6 \mathrm{~mm} \times 150 \mathrm{~mm})$ type UG 120 from Phenomenex (Torrance, CA) was kept at $30^{\circ} \mathrm{C}$. The methanol-water (67:33 by volume) used as the mobile phase was filtered and degassed. After extraction of metabolites of vitamin D from $200 \mu \mathrm{L}$ of serum in isopropanol-toluene $(25: 75 \mathrm{vol} / \mathrm{vol})$, the dried extract was reconstituted in hexane. We used a SEP-PAK column for final cleaning and preparation for HPLC analysis.

\section{Statistical analysis}

The Student's $t$ test was used for comparisons of serum concentration of metabolites. Data were analyzed using Excel software and presented as mean $\pm \mathrm{SD}$. The contribution of each variable in explaining the measured level of $25-(\mathrm{OH})-\mathrm{D}$ and $1,25-(\mathrm{OH})_{2}-\mathrm{D}$ was determined using multiple regression analysis.

\section{Results}

All rats (lean and obese) gained weight during the course of this experiment, and as expected, the obese rats gained significantly $(\mathrm{P}<0.001)$ more weight than lean rats (Table 1$)$. The mean $\pm \mathrm{SD}$ of body weight at 5 and 8 weeks and of serum $25-\mathrm{OH}-\mathrm{D}$ and $1,25-(\mathrm{OH})_{2}-$ $\mathrm{D}$ is summarized in Table 1.

\begin{tabular}{|l|l|l|l|l|}
\hline & \multicolumn{2}{|l|}{ Body weight $(\mathrm{g})$} & $\begin{array}{l}25-(\mathrm{OH})-\mathrm{D} \\
(\mathrm{pmol} / \mathrm{ml})\end{array}$ & $\begin{array}{l}1,25-(\mathrm{OH}) 2-\mathrm{D} \\
(\mathrm{pmol} / \mathrm{ml})\end{array}$ \\
\hline & 5 weeks & 8 weeks & & \\
\hline Lean & $188 \pm 10$ & $238 \pm 15$ & $41 \pm 8$ & $105 \pm 37$ \\
\hline Obese & $349 \pm 30$ & $467 \pm 45$ & $33 \pm 3$ & $97 \pm 25$ \\
\hline P value & $\mathrm{P}<0.001$ & $\mathrm{P}<0.001$ & 0.013 & 0.30 \\
\hline
\end{tabular}

Table 1: Mean \pm SD of body weights at 5 and 8 weeks and of serum 25$(\mathrm{OH})-\mathrm{D}$ and $1,25-(\mathrm{OH}) 2-\mathrm{D}{ }^{*} \mathrm{P}<0.05 ;{ }^{* *} \mathrm{P}<0.0001$

Figure 1 presents data for the serum concentration of 25-OH-D vitamin $\mathrm{D}$ metabolite in the obese rats which was significantly $(\mathrm{P}<0.05)$ lower compared to the lean group (ranged as $33.08 \pm 3.31$ $\mathrm{pmol} / \mathrm{ml}$ and $41.20 \pm 8.60 \mathrm{pmol} / \mathrm{ml}$, respectively). Figure 2 shows the serum concentration of the 1,25-(OH)2-D vitamin D metabolite in the obese rats, and it was approximately $8 \%$ lower and did not reach a significant $(\mathrm{P}<0.5)$ decrease compared to the lean rats. The average was $96.56 \pm 25.39 \mathrm{pmol} / \mathrm{ml}$ in the obese rats and $104.81 \pm 37.47$ $\mathrm{pmol} / \mathrm{ml}$ in lean rats. We also calculated the ratio of two metabolites of vitamin $\mathrm{D}$ in both groups. The ratio of $1,25-(\mathrm{OH})_{2}-\mathrm{D} / 25-\mathrm{OH}-\mathrm{D}$, in obese animals (Figure 3) was approximately $10 \%$ even higher but not significantly $(\mathrm{P}<0.3)$ compared to the lean group, and the ranges were $2.96 \pm 0.876$ and $2.65 \pm 1.139$, respectively.

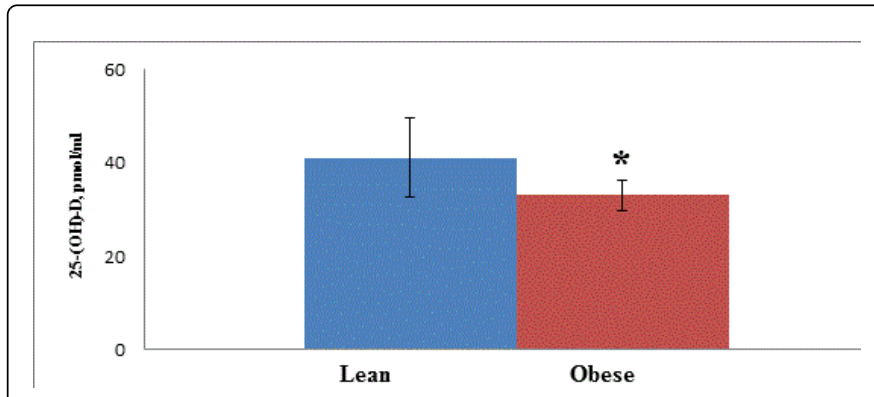

Figure 1: Serum concentration of vitamin D (25- $(\mathrm{OH})-\mathrm{D})$ in lean and obese rats. ${ }^{*} \mathrm{P}<0.05$

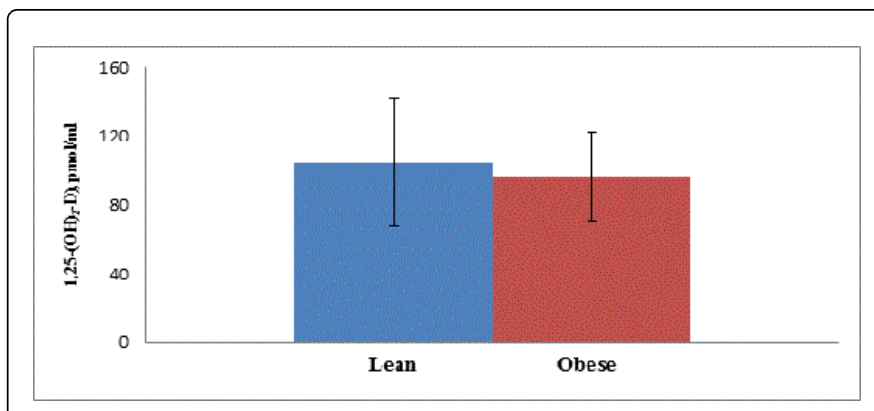

Figure 2: Serum concentration of vitamin $\mathrm{D}\left(1,25-(\mathrm{OH})_{2}-\mathrm{D}\right)$ in lean and obese rats.

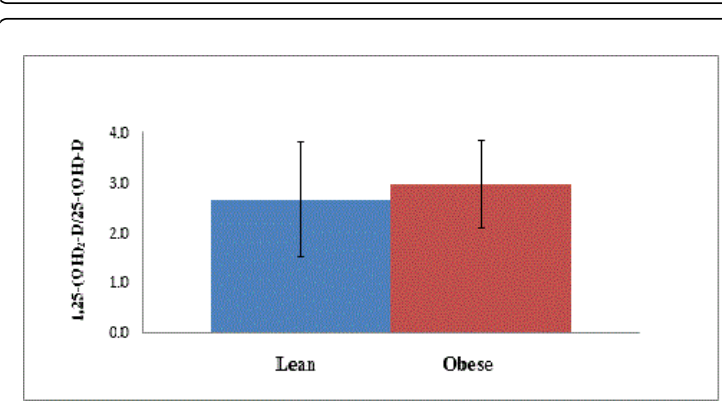

Figure 3: Serum ratios of $1,25-(\mathrm{OH})_{2}-\mathrm{D} / 25-(\mathrm{OH})-\mathrm{D}$ in lean and obese rats.

Figure 4 presents the correlation coefficient analysis between two metabolites. A slight negative correlation (correlation coefficient -0.23) was observed in both groups. 


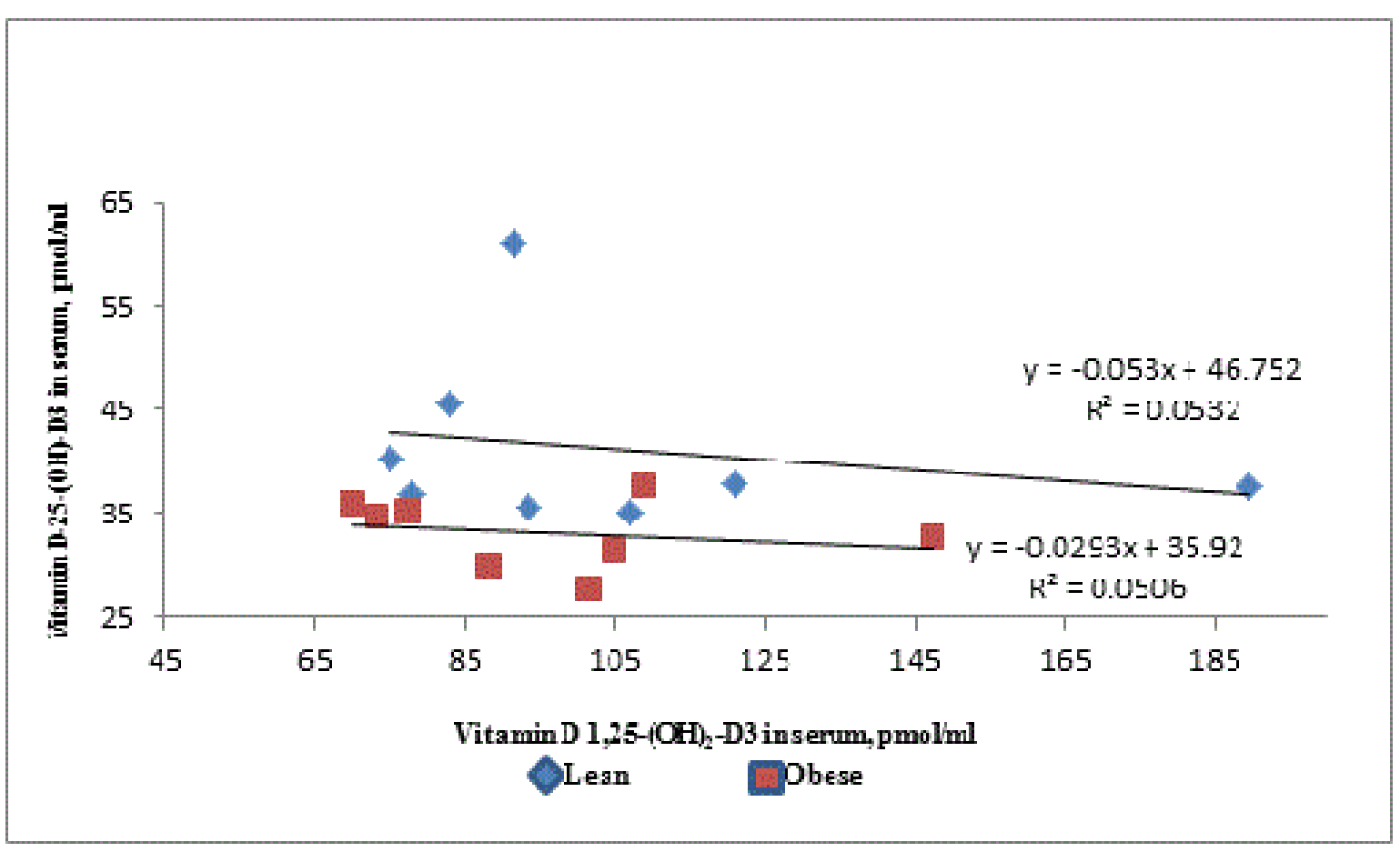

Figure 4: Serum correlation between vitamin D metabolites in lean and obese rats.

\section{Discussion}

It has been reported that both in human and animals, vitamin $\mathrm{D}$ produces a group of fat-soluble metabolites with differing degrees of biological activities responsible for enhancing intestinal absorption of calcium, iron, magnesium, phosphate and zinc [24]. Conversion of 25$(\mathrm{OH})-\mathrm{D}$ (hormonally non-active metabolite) into $1,25-(\mathrm{OH})_{2}-\mathrm{D}$ (hormonally active metabolite) takes place in the kidney. This activation of vitamin $\mathrm{D}$ affects the metabolic pathways of cells. The active metabolite of vitamin $\mathrm{D}$, also called calcitriol, mediates its biological effects by binding to the Vitamin D Receptor (VDR), which is located in the nuclei of target cells and acts as a transcriptional factor that modulates gene expression of certain proteins [25]. This receptor is established in practically all organs and tissues. One very interesting effect of the active form vitamin $\mathrm{D}$ is its involvement in cell proliferation and differentiation of blood immune cells including monocytes and $\mathrm{T}$ and B lymphocytes [26]. The role of macrophages accumulating in the White Adipose Tissue (WAT) during obesity, promoting WAT inflammation and insulin resistance is well established [27,28].

In the present study, we found that obesity caused a significant decrease of serum concentration of the hormonally non-active metabolite of vitamin D (25-OH-D) in rats. This fact can be interpreted as deficiency in biosynthesis of this metabolite or a higher rate of conversion to the active form and as a precursor for converting it to active form resulting from much higher demand of fat tissue for the active form of vitamin D. Our results are also consistent with other studies in humans. There are several reports that low plasma/serum concentrations of vitamin $\mathrm{D}$ are accompanied with obesity in pediatric patients [29,30], in adult women [31], different ethnicities [32] and older populations [33]. In analyzing serum concentrations for the hormonally active metabolite of vitamin $\mathrm{D}$ in obese and lean rats, we found no significant differences between the two groups. However, it was a tendency to see a decreased concentration of this metabolite in obese animals. The slightly lower plasma concentration of the hormonally active form can be a consequence of a more rapid rate of formation to keep up with a much higher demand from the cells for this metabolite in obese rats. When we compared vitamin-D ratio 1,25- $(\mathrm{OH})_{2}-\mathrm{D}: 25-\mathrm{OH}-\mathrm{D}$, we did not find any significant changes. The ratio has the same direction between two groups as the active form has, which surprised us despite a significant decrease in obese animal concentration of 25-OH-D.

After performing a correlation analysis (Figure 4) between these two metabolites in lean and obese groups of rats, we found a slight negative correlation (correlation coefficient -0.23 ) between them: a decrease in the concentration of the non-active metabolite in serum leads to an increased concentration of the active metabolite. This correlation would probably be more significant if the number of experimental animals per group had been increased.

In summary, based on our results we can conclude that lower concentrations of 25-OH-D (vitamin D hormonally non-active form) metabolite are consistent with higher body weight in rats and resonate with human studies. It also can be a predictable enough indicator for assessment of vitamin D status in rats in future experiments.

\section{Acknowledgements}

This study was supported through awards by the UAMS College of Medicine University Medical Group and by the Arkansas Biosciences Institute through the Arkansas Children's Hospital Research Institute to RH. The authors would like to thank John Gregan at the Arkansas 
Children's Hospital Research Institute for valuable assistance with preparation of this manuscript.

\section{References}

1. Pi-Sunyer FX (2002) The obesity epidemic: pathophysiology and consequences of obesity. Obes Res 10 Suppl 2: 97S-104S.

2. Jensen M, Ryan D, Apovian C, Loria C, Ard J, et al. (2014) 2013 AHA/ACC/TOS Guideline for the Management of Overweight and Obesity in Adults: A Report of the American College of Cardiology/ American Heart Association Task Force on Practice Guidelines and The Obesity Society. J Am Coll Cardiol 63: 2985-3023.

3. Javed F, Aziz EF, Sabharwal MS, Nadkarni GN, Khan SA, et al. (2011) Association of BMI and cardiovascular risk stratification in the elderly African-American females. Obesity (Silver Spring) 19: 1182-1186.

4. Donohoe CL, O'Farrell NJ, Doyle SL, Reynolds JV (2014) The role of obesity in gastrointestinal cancer: evidence and opinion. Therap Adv Gastroenterol 7: 38-50.

5. Lim S, Kim KM, Kim MJ, Woo SJ, Choi SH, et al. (2013) The association of maximum body weight on the development of type 2 diabetes and microvascular complications: MAXWEL study. PLoS One 8: e80525.

6. Ding C, Gao D, Wilding J, Trayhurn P, Bing C (2012) Vitamin D signalling in adipose tissue. Br J Nutr 108: 1915-1923.

7. Vanlint S (2013) Vitamin D and obesity. Nutrients 5: 949-956.

8. Bell NH, Epstein S, Greene A, Shary J, Oexmann M, et al. (1985) Evidence for alteration of the vitamin D-endocrine system in obese subjects. J Clin Invest76: 370-373.

9. Liel Y, Ulmer E, Shary J, Hollis BW, Bell NH (1988) Low circulating vitamin D in obesity. Calcif Tissue Int 43: 199-201.

10. Rejnmark L, Vestergaard P, Heickendorff L, Mosekilde L (2008) Plasma $1,25(\mathrm{OH}) 2 \mathrm{D}$ levels decrease in postmenopausal women with hypovitaminosis D. Eur J Endocrinol 158: 571-576.

11. Cipriani C, Pepe J, Piemonte S, Colangelo L, Cilli M, et al. (2014) Vitamin $\mathrm{d}$ and its relationship with obesity and muscle. Int J Endocrinol 2014: 841248 .

12. Fung GJ, Steffen LM, Zhou X, Harnack L, Tang W, et al. (2012) Vitamin $\mathrm{D}$ intake is inversely related to risk of developing metabolic syndrome in African American and white men and women over $20 \mathrm{y}$ : the Coronary Artery Risk Development in Young Adults study. Am J ClinNutr 96: 24-29.

13. Lagunova Z, Porojnicu AC, Lindberg FA, Aksnes L, Moan J (2011) Vitamin D status in Norwegian children and adolescents with excess body weight. Pediatr Diabetes 12: 120-126.

14. Lagunova Z, Porojnicu AC, Vieth R, Lindberg FA, Hexeberg S, et al (2011) Serum 25-hydroxyvitamin D is a predictor of serum 1,25dihydroxyvitamin D in overweight and obese patients. J Nutr 141: 112-117.

15. Bouillon R, Carmeliet G, Lieben L, Watanabe M, Perino A, et al. (2014) Vitamin D and energy homeostasis--of mice and men. Nat Rev Endocrinol 10: 79-87.

16. Ishida H, Seino Y, Matsukura S, Ishizuka S, Imura H (1985) The role of vitamin $\mathrm{D}$ metabolites in hypercalcemia of Zuckerfa/fa rats. J NutrSciVitaminol (Tokyo) 31: 1-5.
17. Chang-Quan H, Bi-Rong D, Ping H, Zhen-Chan L, Xiao-Dong P (2008) Insulin resistance, renal injury, renal 1-alpha hydroxylase, and bone homeostasis in aged obese rats. Arch Med Res 39: 380-387.

18. Roth CL, Elfers CT, Figlewicz DP, Melhorn SJ, Morton GJ, et al. (2012) Vitamin D deficiency in obese rats exacerbates nonalcoholic fatty liver disease and increases hepatic resistin and toll-like receptor activation. Hepatology55: 1103-1111.

19. Wei M, Yu R, Deutsch SC (2014) Insignificant medium-term vitamin d status change after 25-hydroxyvitamin $\mathrm{d}$ testing in a large managed care population. PLoS One 9: e105571.

20. Laczmanski L, Milewicz A, Puzianowska-Kuznicka M, Lwow F, Kolackov $\mathrm{K}$, et al. (2014) Interrelation between genotypes of the vitamin D receptor gene and serum sex hormone concentrations in the Polish elderly population: the PolSenior study. Experimental Gerontology 57:188-190.

21. Hakkak R, Shaaf S, Jo CH, Macleod S, Korourian S (2011) Effects of highisoflavone soy diet vs. casein protein diet and obesity on DMBA-induced mammary tumor development. OncolLett 2: 29-36.

22. Hakkak R, Al-Dwairi A, Fuchs G, Korourian S, Simmen F (2012) Dietary soy protein induces hepatic lipogenic enzyme gene expression while suppressing hepatosteatosis in obese female Zucker rats bearing DMBAinitiated mammary tumors. Genes \& Nutrition 7: 549-558.

23. Lensmeyer GL, Wiebe DA, Binkley N, Drezner MK (2006) HPLC method for 25-hydroxyvitamin D measurement: comparison with contemporary assays. ClinChem 52: 1120-1126.

24. Holick MF (2006) High prevalence of vitamin D inadequacy and implications for health. Mayo ClinProc 81: 353-373.

25. Delvin E, Souberbielle JC, Viard JP, Salle B (2014) Role of vitamin D in acquired immune and autoimmune diseases. Crit Rev Clin Lab Sci 51: 232-247.

26. Bell TD, Demay MB, Burnett-Bowie SA (2010) The biology and pathology of vitamin D control in bone. J Cell Biochem 111: 7-13.

27. Chatzigeorgiou A, Karalis KP, Bornstein SR, Chavakis T (2012) Lymphocytes in obesity-related adipose tissue inflammation. Diabetologia 55: 2583-2592.

28. Mutt SJ, Hyppönen E, Saarnio J, Järvelin MR, Herzig KH (2014) Vitamin $\mathrm{D}$ and adipose tissue-more than storage. Front Physiol 5: 228.

29. Robinson C, Chiang M, Thompson SN, Sondike SB (2012) Occurrence of vitamin D deficiency in pediatric patients at high risk in West Virginia. South Med J 105: 504-507.

30. Lee S, Kim S, Park H, Choi K, Cho G, et al. (2013) Serum 25hydroxyvitamin D levels, obesity and the metabolic syndrome among Korean children. Nutrition, Metabolism and Cardiovascular Diseases 23: 785-791.

31. Tamer G, Mesci B, Tamer I, Kilic D, Arik S (2012) Is vitamin D deficiency an independent risk factor for obesity and abdominal obesity in women? Endokrynol Pol 63: 196-201.

32. Sulistyoningrum DC, Green TJ, Lear SA, Devlin AM (2012) Ethnicspecific differences in vitamin D status is associated with adiposity. PLoS One 7: e43159.

33. Jungert A, Roth HJ, Neuhauser-Berthold M (2012) Serum 25hydroxyvitamin D3 and body composition in an elderly cohort from Germany: a cross-sectional study. Nutr Metab 9: 42. 